\title{
A Study on Investors Perception Towards Sharemarket in Sharekhan Ltd.
}

\author{
Vijay. S*, Dr. Ch. Balanageswara Rao \\ *Student \\ Saveetha School of Management, Chennai, Tamil Nadu, India
}

\begin{abstract}
The globalization of financial markets has been increasing the size of the community of retail investors' over the past two decades by providing a wide variety of market and investment options. Hence, it makes their investment decisions process more complex. The factors influencing investor's perception are return on investment, market trend or risk, short term profitability, price of the share, dividend policy, past financial performance, company reputation, reputation of the board, current earnings of the company and expert opinion. This study focuses the main factors influencing investor's perception.
\end{abstract}

\section{Keyword: Investors Perception in Share Market}

\section{INTRODUCTION}

Indian Stock Markets is one of the oldest in Asia. Its history dates back to nearly 200 years ago. The earliest records of security dealings in India are meager and obscure. The East India Company was the dominant institution in those days and business in its loan securities used to be transacted towards the close of the eighteenth century.

By 1830's business on corporate stocks and shares in Bank and Cotton presses took place in Bombay. Though the trading list was broader in 1839, there were only half a dozen brokers recognized by banks and merchants during 1840 and 1850. The 1850's witnessed a rapid development of commercial enterprise and brokerage business attracted many men into the field and by 1860 the number of brokers increased into 60. In 1860-61 the American Civil War broke out and cotton supply from United States to Europe was stopped; thus, the 'Share Mania' in India began. The number of brokers increased to about 200 to 250 .
At the end of the American Civil War, the brokers who thrived out of Civil War in 1874, found a place in a street (now appropriately called as Dalal Street) where they would conveniently assemble and transact business. In 1887, they formally established in Bombay, the "Native Share and Stock Brokers' Association", which is alternatively known as "The Stock Exchange". In 1895, the Stock Exchange acquired a premise in the same street and it was inaugurated in 1899. Thus, the Stock Exchange at Bombay was consolidated.

\section{BOMBAY STOCK EXCHANGES:}

The Bombay Stock Exchange (BSE) is a stock exchange located on Dalal Street, Mumbai and is the oldest stock exchange in Asia. The equity market capitalization of the companies listed on the BSE wasUS $\$ 1$ trillion as of December2011, making it the 6th largest stock exchange in Asia and the 14th largest in the world. The BSE has the largest number of listed companies in the world. As of December 2011, there are over 5,112 listed Indian companies and over 8,196 scrip on the stock exchange, the Bombay Stock Exchange has a significant trading volume This stock exchange, Mumbai, popularly known as "BSE" was established in 1875 as "The Native share and stock brokers association", as a voluntary non- profit making association. It has an evolved over the years into its present status as the premiere stock exchange in the country. It may be noted that the stock exchanges the oldest one in Asia, even older than the Tokyo Stock Exchange, which was founded in 1878. The exchange, while providing an efficient and transparent market for trading in securities, upholds the interests of the investors and ensures redressed of their grievances, whether against the companies or its own member brokers. It also strives to educate and 
enlighten the investors by making available necessary informative inputs and conducting investor education programs.

\section{BSE INDICES}

In order to enable the market participants, analysts etc., to track the various ups and downs in the Indian stock market, the Exchange has introduced in 1986 an equity stock index called BSE- SENSEX that subsequently became the barometer of the moments of the share prices in the Indian Stock market. It is a "Market capitalization weighted" index of 30 component stocks representing a sample of large, well-established and leading companies. The base year of Sensex is 1978-79. The Sensex is widely reported in both domestic and international markets through print as well as electronic media. Sensex is calculated using a market capitalization weighted method. As per this methodology, the level of the index reflects the total market value of all 30component stocks from different industries related to particular base period. The total market value of a company is determined by multiplying the price of its stock by the number of shares outstanding. Statisticians call an index of a set of combined variables (such as price and numberof shares) a composite Index. An Indexed number is used to represent the results of this calculation in order to make the value easier to work with and track over at time. It is much easier to graph a chart based on Indexed values than one based on actual values world over majority of the well-known indices are constructed using "Market capitalization weighted method" .In practice, the daily calculation of SENSEX is done by dividing the aggregate market value of the 30 companies in the Index by a number called the Index Divisor. The Divisor is the only link to the original base period value of the SENSEX. The Divisor keeps the Index comparable over a period or time and if the reference point for the entire Index maintenance adjustments. SENSEX is widely used to describe the mood in the Indian Stock markets. Base year average is changed as per the formula new base year average $=$ old base year average* (new marker value/old market value)

\section{NATIONAL STOCK EXCHANGE:}

NSE was set up with the objectives of: 1. establishing a nationwide trading facility for all type of securities. 2. Ensuring equal access to investors all over the country through an appropriate communication network. 3. Providing a fair, efficient and transparent securities market using electronic trading system .The NSE was incorporated in Now 1992 with an equity capital of Rs 25crores. The International security consultancy (ISC) of Hong Kong has helped in setting up NSE.ISE has prepared the detailed business plans and installation of hardware and software system. It has been set up to strengthen the move towards professionalization of the capital market as well as provide nationwide securities trading facilities to investors.NSE is not an exchange in the traditional sense where brokers own and manage the exchange. The National Stock Exchange (NSE) is India's leading stock exchange covering various cities and towns across the country. NSE was set up by leading institutions to provide a modern, fully automated screen-based trading system with national reach. The Exchange has brought about unparalleled transparency, speed \& efficiency, safety and market integrity. It has set up facilities that serve as a model for the securities industry in terms of systems, practices and procedures.NSE has played a catalytic role in reforming the Indian securities market in terms of micro structure, market practices and trading volumes. The market today uses state-of-art information technology to provide an efficient and transparent trading, clearing and settlement mechanism, and has witnessed several innovations in products \& services viz. demutualization of stock exchange governance, screen based trading, compression of settlement cycles, dematerialization and electronic transfer of securities, securities lending and borrowing, professionalization of trading members, fine-tuned risk management systems, emergence of clearing corporations to assume counterpart risks ,market of debt and derivative instruments and intensive use of information technology.

\section{NSE-NIFTY}

The National Stock Exchange of India Limited (NSE) is the leading stock exchange of India, located in Mumbai. NSE was established in 1992 as the first demutualized electronic exchange in the country. NSE was the first exchange in the country to provide a modern, fully automated screen-based electronic trading system which offered easy trading facility to the investors spread across the length and breadth of the country.

NSE has a market capitalization of more than US\$1.65 trillion, making it the world's 12th- largest stock exchange as of 23 January 2015. NSE's flagship 
index, the Nifty, the 50 stock indexes, is used extensively by investors in India and around the world as a barometer of the Indian capital markets.

The NSE on April 22, 1996 launched a new equity Index, NSE-50. The new index, which replaces the existing NSE-100 index, is expected to serve as an appropriate Index for the new segment of futures and "Nifty" means National Index for Fifty Stocks. The NSE-50 comprises 50 companies that represent 20 broad Industry groups with an aggregate market capitalization of around Rs. 1,70,000crs. All companies included in the Index have a market capitalization in excess of Rs 500crs each and should have traded for $85 \%$ of trading days at an impact cost of less than $1.5 \%$. The base period for the index is the close of prices on Nov 3, 1995, which makes one year of completion of operation of NSE ${ }^{\text {ee }}$ s capital market segment. The base value of the index has been set at 1000 .

\section{NEED OF THE STUDY}

The need of the study was to fill the gap that was identified in the previous researches. The researchers conducted earlier lay emphasis on the working of Indian Stock Market. Considering the ample importance of this aspect, the present study was conducted to know the Indian Stock Market \& various options available in the Stock Market to invest \& study the behavior of investors and determine their awareness level regarding various investment avenues available in stock market.

\section{SCOPE OF THE STUDY}

The scope of the study was limited to Chennai city.

\section{OBJECTIVES OF THE STUDY}

The study has been undertaken in order to achieve the following objectives:

$>$ To take an overview of the Indian Stock Market and encapsulate the various investment avenues available.

$>$ To know various options available in the Capital Market to invest.

$>$ To know investor's perception regarding investment in stock market

$>$ To study the investment behavior of investors and the factors that affects their investment decision.

$>$ To study the problems of investors and the reasons for not investing in financial instruments.

$>$ To know the satisfaction level of investors regarding return of different investment avenues.

\section{REVIEW OF LITERATURE}

Various studies on Investment pattern \& Investment behavior of investors had been conducted in foreign countries. However, in Indian context, the number is quite few. Depending on the various issues of investment, the review has been discussed in brief as follows:

Charles (1999) has analyzed that the astonishing growth in Americans' stock portfolios in the 1990s has been a major force behind the growth of consumer spending. This article reviews the relationship between stock market movements and consumption. Using various econometric techniques and specifications, the authors find that the propensity to consume out of aggregate household wealth has exhibited instability over the postwar period. They also show that the dynamic response of consumption growth to an unexpected change in wealth is extremely short- lived, implying that forecasts of consumption growth one or more quarters ahead are not typically improved by accounting for changes in existing wealth.

Bhardwaj (2003) has stated the literature on globalization; He found the pervasiveness of the west's perception of the world affect on Indian investors that affects the trends in investor's choice. They are hugely affected by the west's views and so changes in Indian trends occur.

Ranganathan (2003) has stated the investor behavior from the marketing world and financial economics has brought together to the surface an exciting area for study and research: behavioral finance. The realization that this is a serious subject is, however, barely dawning. Analysts seem to treat financial markets as an aggregate of statistical observations, technical and fundamental analysis. A rich view of research waits this sophisticated understanding of how financial markets are also affected by the 'financial behavior' of investors. With the reforms of industrial policy, public sector, financial sector and the many developments in the Indian money market and capital market, mutual funds that has become an important portal for the small investors, is also influenced by their financial behavior. Hence, this study has made an attempt to examine the related aspects of the fund selection behavior of individual investors towards Mutual funds, in the city of Mumbai. From the researchers and academicians point of view, such a study will help in developing and expanding 
knowledge in this field. Shrotriya (2003) conducted a survey on investor preferences in which he depicted the linkage of investment with the factor so considered while making investment. He says "There are various factors and their linkage also. These factors help us how to ensure safety, liquidity, capital appreciation and tax benefits along with returns."

Dijk (2007) has conducted 25 years of research on the size effect in international equity returns. Since Banz's (1981) original study, numerous papers have appeared on the empirical regularity that small firms have higher risk-adjusted stock returns than large firms. A quarter of a century after its discovery, the outlook for the size effect seems bleak. Yet, empirical asset pricing models that incorporate a factor portfolio mimicking underlying economic risks proxied by firm size are increasingly used by both academics and practitioners. Applications range from event studies and mutual fund performance measurement to computing the cost of equity capital. The aim of this paper is to review the literature on the size effect and synthesize the extensive debate on the validity and persistence of the size effect as an empirical phenomenon as well as the theoretical explanations for the effect. We discuss the implications for academic research and corporate finance and suggest a number of avenues for further research.

Vasudev (2007) analysed the developments in the capital markets and corporate governance in India since the early 1990s when the government of India adopted the economic liberalization programmed. The legislative changes significantly altered the theme of Indian Companies Act 1956, which is based on the Companies Act 1948 (UK). The amendments, such as the permission for nonvoting shares and buybacks, carried the statute away from the earlier "business model" and towards the 'financial model' of the Delaware variety. Simultaneously, the government established the Securities Exchange Board of India (SEBI), patterned on the Securities and Exchange Commission of US. Through a number of other policy measures, the government steered greater investments in the stock market and promoted the stock market as a central institution in the society. The article points out that the reform effort was inspired, at least in part, by the government's reliance on foreign portfolio inflows into the Indian stock market to fund the country's trade and current account deficits. Johnson (2008) has stated that Product quality is probably under-valued by firms because there is little consensus about appropriate measures and methods to research quality. The authors suggest that published ratings of a product's quality are a valid source of quality information with important strategic and financial impact. The authors test this thesis by an event analysis of abnormal returns to stock prices of firms whose new products are evaluated in the Wall Street Journal. Quality has a strong immediate effect on abnormal returns, which is substantially higher than that for other marketing events assessed in prior studies. In dollar terms, these returns translate into an average gain of $\$ 500$ million for firms that got good reviews and an average loss of $\$ 200$ million for firms that got bad reviews. Moreover, there are some important asymmetries. Rewards to small firms with good reviews of quality are greater than those to large firms with good reviews. On the other hand, large firms are penalized more by poor reviews of quality than they are rewarded for good reviews. The authors discuss the research, managerial, investing, and policy implications.

Patnaik and shah (2008) has analysed on the preferences of foreign and domestic institutional investors in Indian stock markets. Foreign and domestic institutional investors both prefer larger, widely dispersed firms and do not chase returns. However, we and evidence of strong differences in the behavior of foreign and domestic institutional investors.

Bhatnagar (2009) has analysed of Corporate Governance and external finance in transition economies like India. The problem in the Indian corporate sector is that of disciplining the dominant shareholder and protecting the minority shareholders. Clearly, the problem of corporate governance abuses by the dominant shareholder can be solved only by forces outside the company itself particularly that of multilateral financial institutions in the economic development. India has relied heavily on external finance as their domestic saving rates have been much lower than their investment rates. The less promising prospects for the global supply of external finance the need for an increase in the multilateral financial institutions. India being a transition economy is changing from a centrally planned economy to a free market. It is undergoing economic liberalization, macroeconomic stabilization where immediate high inflation is brought under control, and restructuring and privatization in order to create a financial sector and move from public to private ownership of 
resources. These changes often may lead to increased inequality of incomes and wealth, dramatic inflation and a fall of GDP.

Mayank (2009) has analysed the role of two important forces - the regulator and the capital market as determinant of external finance in transition economies analyses the changing pattern and future prospectus of external finance to India and reviews the role of external finance. Under this framework, the study evaluates current Indian corporate governance practices in light of external finance.

From the above reviews it can be concluded that many researches had been conducted before relating to the investment patterns and the few researchers studied the literature only on the basis of returns. Analysts treated financial markets as an aggregate of statistical observations, technical and fundamental analysis but no researches had been conducted on Impact of global factors on Indian Economy. This gap had been identified so that in this respect present study had been conducted

\section{RESEARCH METHODOLOGY}

Research Methodology is a way to systematically solve the research problem. The Research Methodology includes the various methods and techniques for conducting a research. Research is an art of scientific investigation. In other word research is a scientific and systematic search for pertinent information on a specific topic. The logic behind taking research methodology into consideration is that one can have knowledge about the method and procedure adopted for achievement of objective of the project.

\section{RESEARCH DESIGN:}

Research design is the empirical structure within which research is conducted. It constitutes the blueprint for collection, measurement and analysis of data was a descriptive research. Descriptive research involves collecting numerical through self-reports collected, through questionnaires or interviews (person or phone), or through observation. For present study, the research was descriptive and conclusion oriented.

\section{SAMPLING DESIGN:}

Universe: The Universe is most commonly defined as everything that physically exists: the entirety of space and time, all forms of matter, energy and momentum, and the physical laws and constants that govern them. All those persons who make investment.

Theoretical Universe: It included investors make investment in all over world.

Accessible Universe: It included investors make investment in Indian Stock Market.

Sampling unit - The target population must be defined that has to be sampled. The sampling unit of research included students and professionals residing in Chennai city.

Sample size - This refers to number of respondents to be selected from the universe to constitute a sample. The sample size of 100 Investors was taken.

Sampling Technique - Convenience Sampling was used to select the sample. Convenient sampling is a non probability sampling technique that attempts to obtain a sample of convenient elements .In case of convenience sampling, the selection of sample depends upon the discretion of the interviewer. In this project, Questionnaire Method was used for the collecting the data. With the help of this method of collecting data, a sample survey was conducted.

\section{DATA COLLECTION AND ANALYSIS:}

Information has been collected from both Primary and Secondary Data.

Secondary sources- Secondary data are those which have already been collected by someone else and which already had been passed through the statistical process. The secondary data was collected through web sites, books and magazines.

Primary sources- Primary data are those which are fresh and are collected for the first time, and thus happen to be original in character. The primary data was collected through direct personal interviews (open ended and close ended questionnaires)

\section{DATA ANALYSIS}

The collected data is sorted out and analyzed to prepare the final report. The tools and techniques used in the analysis are.

\section{Tools for analysis}

$>$ Frequency Analysis

$>$ One Way ANOVA 
International Journal of Trend in Scientific Research and Development (IJTSRD) ISSN: 2456-6470

DATA ANALYSIS AND INTERPRETATION

Table 4.9 Analysis of Out of following which type of investment you aware of share market

\begin{tabular}{|c|c|c|c|}
\hline \multicolumn{1}{|c|}{} & Frequency & Percent \\
\cline { 2 - 4 } & Share & 38 & 37.6 \\
\cline { 2 - 4 } Valid & Bonds & 20 & 19.8 \\
\cline { 2 - 4 } & Derivatives & 17 & 16.8 \\
\cline { 2 - 4 } & Mutual fund & 12 & 11.9 \\
\cline { 2 - 4 } & Debentures & 13 & 13.9 \\
\cline { 2 - 4 } & Total & 100 & 100.0 \\
\hline
\end{tabular}

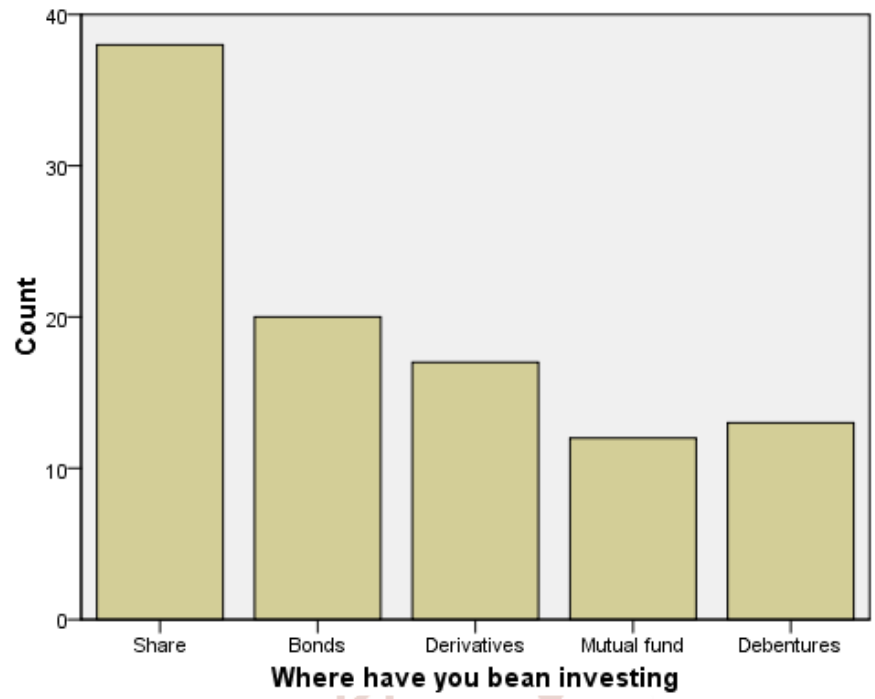

\section{INTERPRETATION:}

The above table and chart shows that $38 \%$ of the investors invest in share, $20 \%$ of the investors invest in bond, $17 \%$ of the investors invest in debentures, $12 \%$ of the investors invest in mutual fund, and $13 \%$ of the investors invest in derivatives. The majority of them replied $38 \%$ in share.

Table 4.10 Analysis of sector specific stock you have

\begin{tabular}{|c|c|c|c|}
\hline \multicolumn{2}{|c|}{} & Frequency & Percent \\
\hline \multirow{4}{*}{ Valid } & IT sector & 13 & 12.9 \\
\cline { 2 - 4 } & Banking sector & 28 & 27.7 \\
\cline { 2 - 4 } & FMGC & 19 & 18.8 \\
\cline { 2 - 4 } & Energy sector & 19 & 18.8 \\
\cline { 2 - 4 } & Pharma sector & 11 & 11.9 \\
\cline { 2 - 4 } & Others & 10 & 9.9 \\
\cline { 2 - 4 } & Total & 100 & 100.0 \\
\hline
\end{tabular}

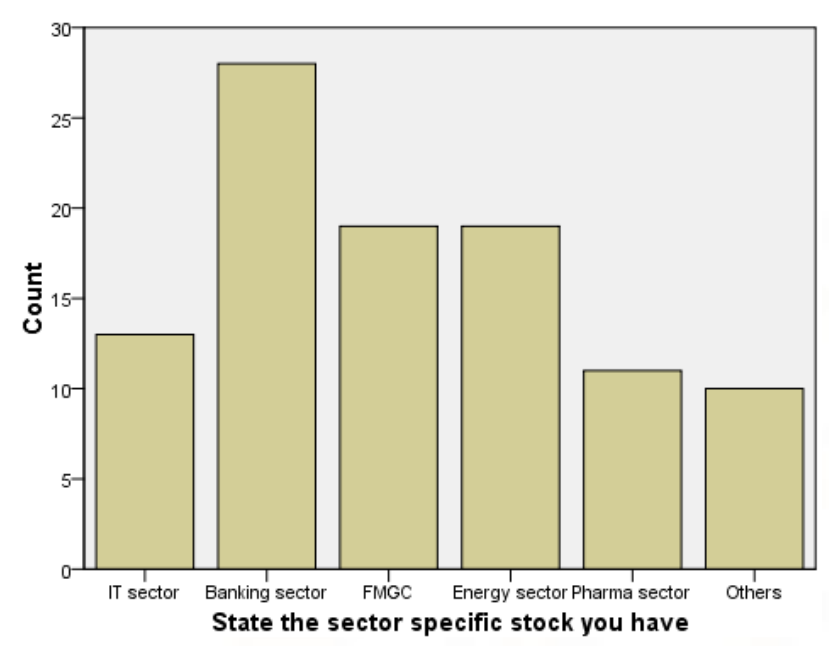

\section{INTERPRETATION:}

The above table and chart shows that $28 \%$ of the investor invest in banking sector, $19 \%$ of the investors invest in FMGC, $19 \%$ of the investors invest in energy sector, $13 \%$ of the investors invest in IT sector, $11 \%$ investors invest in Parma sector, $10 \%$ of the investors invest in others, The majority of the people replied that $28 \%$ of them are invest in banking sector.

Table 4.11 Analysis which of rate investor to grow

\begin{tabular}{|c|c|c|c|}
\hline \multicolumn{2}{|c|}{} & Frequency & Percent \\
\hline \multirow{3}{*}{ Valid } & Steadily & 37 & 36.6 \\
\cline { 2 - 4 } & At an average rate & 29 & 28.7 \\
\cline { 2 - 4 } & At fast rate & 34 & 34.7 \\
\cline { 2 - 4 } & Total & 100 & 100.0 \\
\hline
\end{tabular}

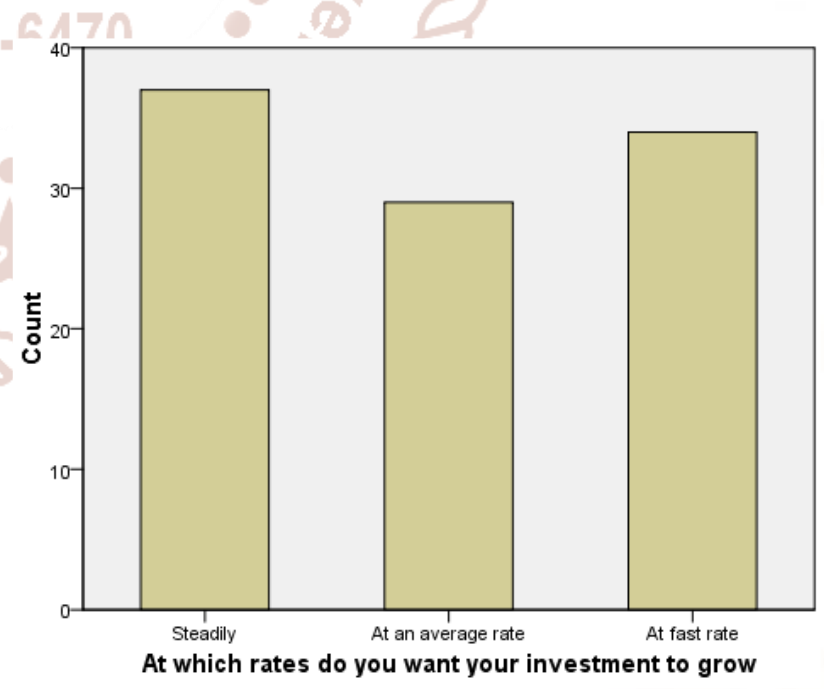

\section{INTERPRETATION:}

The above table and chart shows that $37 \%$ of them investors investment in steadily, $34 \%$ of the investors investment in at fast rate, and $29 \%$ of the investors investment in at an average rate. The majority of the people $37 \%$ of them investment in steadily. 
Table 4.12 Analysis of frequently do you want to invest

\begin{tabular}{|c|c|c|c|}
\hline \multicolumn{2}{|c|}{} & Frequency & Percent \\
\hline \multirow{4}{*}{ Valid } & Daily & 21 & 20.8 \\
\cline { 2 - 4 } & Monthly & 29 & 28.7 \\
\cline { 2 - 4 } & Weakly & 28 & 27.7 \\
\cline { 2 - 4 } & Yearly & 22 & 22.8 \\
\cline { 2 - 4 } & Total & 100 & 100.0 \\
\hline
\end{tabular}

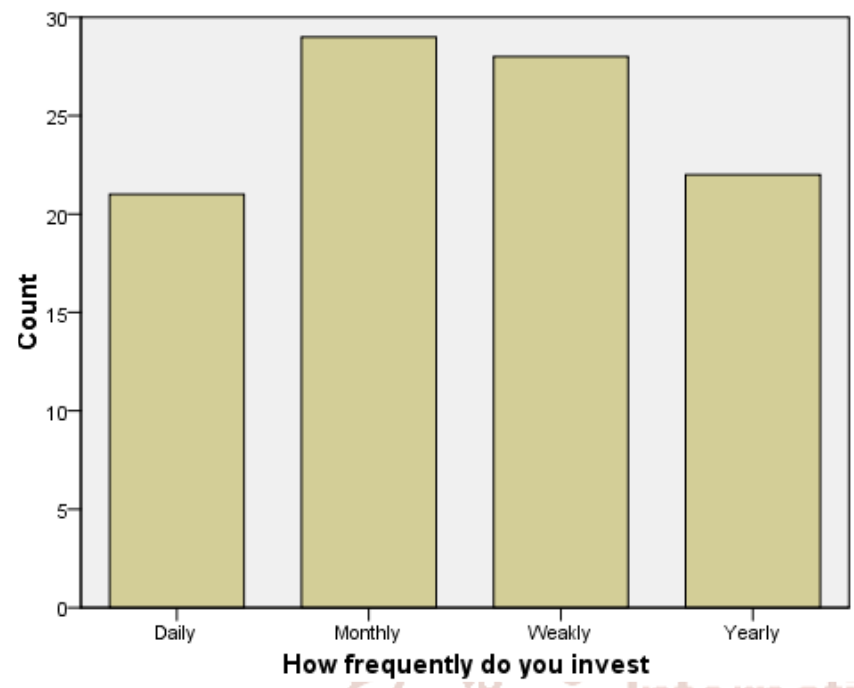

INTERPRETATION:

The above table and chart shows that $29 \%$ of the investors invest in monthly, $28 \%$ of the investors invest in weakly, $22 \%$ of the investors invest in yearly, $21 \%$ of the investors invest in daily. The majority of the investors $29 \%$ of the investment in monthly.

Table 4.15 Analysis of considerer before investing in share market

\begin{tabular}{|c|c|c|c|}
\hline \multicolumn{2}{|c|}{} & Frequency & Percent \\
\hline \multirow{7}{*}{ Valid } & Capital Appreciation & 15 & 14.9 \\
\cline { 2 - 4 } & Maturity Period & 17 & 16.8 \\
\cline { 2 - 4 } & Safety of Principal & 16 & 15.8 \\
\cline { 2 - 4 } & Risk & 19 & 18.8 \\
\cline { 2 - 4 } & Return on investment & 9 & 8.9 \\
\cline { 2 - 4 } & Tax benefits & 7 & 6.9 \\
\cline { 2 - 4 } & Liquidity & 17 & 17.8 \\
\cline { 2 - 4 } & Total & 100 & 100.0 \\
\hline
\end{tabular}

\section{INTERPRETATION:}

The above table and chart shows that $19 \%$ of investors investing in factor consider risk, $17 \%$ of investors investing in factor consider maturity period, $17 \%$ of investor investing in factor consider liquidity, $16 \%$ of investors investing in factor consider safety of principle, $15 \%$ of investor investing in factor consider capital appreciation, 9\% of investors investing in factor consider return on investment, $7 \%$ of investors investing in factor consider tax benefit. The majority replied $19 \%$ investing risk.

\section{ONE WAY ANOVA}

In statistics, one-way analysis of variance (abbreviated one-way ANOVA) is a technique used to compare means of two or more samples (using the $\mathrm{F}$ distribution). This technique can be used only for numerical data.

The ANOVA tests the null hypothesis that samples in two or more groups are drawn from populations with the same mean values. To do this, two estimates are mode of the population variance. These estimates rely on various assumptions. The ANOVA produces an Fstatistic, the ratio of the variance calculated among the means to the variance within the samples. If the group means are drawn from populations with the same mean values, the variance between the group means should be lower than the variance of the samples, following the central limit theorem. A higher ratio therefore implies that the samples were drawn from populations with different mean values.

\section{Difference between age and investing}

Null Hypothesis: There is no significant difference between age and investing

Alternate Hypothesis: There is a significant difference between age and investing 
International Journal of Trend in Scientific Research and Development (IJTSRD) ISSN: 2456-6470

Table 4.2.1Anova for age and investing area

\begin{tabular}{|c|c|c|c|c|c|}
\hline \multicolumn{7}{|c|}{ ANOVA } \\
\hline \multicolumn{5}{|c|}{ Age } \\
\hline Sum of Squares & Df & Mean Square & F & Sig. \\
\hline Between Groups & 2.750 & 4 & .687 & 1.476 & .216 \\
\hline Within Groups & 44.250 & 95 & .466 & & \\
\hline Total & 47.000 & 99 & & & \\
\hline
\end{tabular}

\section{Interpretation}

The significant values is 0.216 which is lesser than 0.200 . Hence, null hypothesis is rejected Alternative hypothesis is accepted. Hence, there is a significant difference between age and investing.

\section{Difference between age and rate of investing}

Null Hypothesis: There is no significant difference between age and rate of investing Alternate Hypothesis: There is a significant difference between age and rate of investing

Table 4.2.2Anova for age and rate of investing

\begin{tabular}{|c|c|c|c|c|c|}
\hline \multicolumn{7}{|c|}{ ANOVA } \\
\hline & Sum of Squares & d f & Mean Square & F & Sig. \\
\hline Between Groups & .794 & 2 & .397 & .833 & .438 \\
\hline Within Groups & 46.206 & 97 & .476 & & \\
\hline Total & 47.000 & 99 & & & \\
\hline
\end{tabular}

\section{Interpretation}

The significant values is 0.438 which is lesser than 0.400 . Hence, null hypothesis is rejected, Alternative hypothesis is accepted. Hence, there is a significant difference between age and rate of investing

\section{Difference between gender and investor experience}

Null Hypothesis: There is no significant difference between gender and investor experience

Alternate Hypothesis: There is a significant difference between gender and investor experience

\section{Table 4.2.3Anova for gender and investor experience}

\begin{tabular}{|c|c|c|c|c|c|}
\hline \multicolumn{6}{|c|}{ ANOVA } \\
\hline & Sum of Squares & D f & Mean Square & F & Sig. \\
\hline Between Groups & .663 & 2 & .332 & 3.022 & .053 \\
\hline Within Groups & 10.647 & 97 & .110 & & \\
\hline Total & 11.310 & 99 & & & \\
\hline
\end{tabular}

\section{Interpretation}

The significant values is 0.53 which is lesser than 0.50 . Hence, null hypothesis is rejected, Alternative hypothesis is accepted. Hence, there is a significant difference between gender and investors experience.

\section{FINDINGS OF THE STUDY}

Following findings were generated from the study:-

1. Maximum investors are aware of all the investment options.

2. Investors do not invest in a single avenue. They prefer different avenues and maximum investors prefer to invest in shares, mutual funds \& debentures.

3. Maximum investors wants their investment grow at fast rate.

4. The investment decision of investors is influenced by their own decision and through service broking.

5. Different factors considered by investors while investing are return, risk, tax benefits, capital appreciation and the most prominent factor is the return on any investment avenue. 
6. Majority of investors invest $10-15 \%$ of their annual income.

7. Maximum investors invest on monthly basis.

8. The investors investing in different avenues are highly satisfied with the return generated by their investment option.

9. Maximum investors have other investment policies.

10. The most important factor is Return which influenced the decision regarding investment.

\section{SUGGESTIONS}

> Sharekhan Stock Broking should to give special preferences to trading via branch network, telephones and Internet account.

> Sharekhan Stock Broking has to improve customized products for lending against shares.

$>$ Integrated Trading and Depositary Account should have to be modified according to the need of the investors.

$>$ Technology transforming desktop should have to be NEAT like terminal for Internet trading.

$>$ One Screen for both Cash and Derivatives Trading system have to be revised and modified..

$>$ Equity Research Department at share khan Stock Broking should have to study the market and provides information.

> sharekhan Stock Broking should have to customized Insurance services.

\section{CONCLUSION}

Indian Stock Markets is one of the oldest in Asia. Its history dates back to nearly 200 years ago. The earliest records of security dealings in India are meager and obscure. The East India Company was the dominant institution in those days and business in its loan securities used to be transacted towards the close of the eighteenth century. The nature of investment differs from individual to individual and is unique to each one because it depends on various parameters like future financial goals, the present \& the future income model, capacity to bear the risk, the present requirements and lot more. As an investor progresses on his/her life stage and as his/her financial goals change, so does the unique investor profile. Maximum investors are aware of all the investment options. Investors do not invest in a single avenue. They prefer different avenues and maximum investors prefer to invest in shares, mutual funds \& debentures. The investment decision of investors is influenced by their own decision and through friends \& relatives. Majority of investors invest $15-20 \%$ of their annual income.. The most important factor is Return which influenced the decision regarding investment.

In today's scenario when all services are going online or in electronic form Sharekhan Stock Broking is creating awareness of online trading that client can trade from anywhere from the World.

Risk management team of Sharekhan Stock Broking taking care of client portfolio and whenever the value of his portfolio will go decrease by $30 \%$ client always informed by his Relationship Manager.

In Sharekhan Stock Broking possibility of auction is very less because of large client base, so he can sell shares anytime.

\section{BIBLIOGRAPHY}

1. Charles (1999). Economic Policy, Astonishing growth in Americans' stock portfolios. The Icfai Journal of Stock Market, 6 (3): 43-60. Available at http://papers.ssrn.com/sol3/results.cfm last accessed on July5, 2009.

2. Dijk (2007). Economic Policy, The Size Effect in Equity Returns. Empirical Research Findings. Journal of Financial Management and Analysis, 21(1). Available at http://papers.ssrn.com/sol3/results.cfm last accessed on July5, 2009.

3. Johnson (2008). The Value of Quality: Stock Market Returns to Published Quality Reviews. The Icfai Journal of Applied Economics, 7(3):722. Available at http://papers.ssrn.com/sol3/results.cfm last accessed on June5, 2009.

4. Mayank (2009). Performance Corporate Governance as a Determinant of External Finance in Transition Economies: A Case Study of India .The Icfai University Journal of Applied Economics, 8(1): 31- 44. Available at http://papers.ssrn.com/sol3/results.cfm last accessed on June 5,2009

5. Introduction on Indian Stock Market available at http://www.banknetindia.com/ last accessed on November 5, 2009.

6. Introduction on Online Investors \& Traders available at http://www.traderji.com/ last accessed on November 17, 2009

7. Introduction on Types of investment available at http://finance.mapsofworld.com/investment/types/ last accessed on November 17, 2009. 